Original Scientific Article

\title{
DEVELOPMENT OF SIMPLE MULTIPLEX REAL-TIME PCR ASSAYS FOR FOODBORNE PATHOGENS DETECTION AND IDENTIFICATION ON LIGHTCYCLER
}

\author{
Avo Karus ${ }^{1}$, Fabrizio Ceciliani ${ }^{2}$, Armand Sanches Bonastre ${ }^{3}$, Virge Karus ${ }^{1}$ \\ ${ }^{1}$ Department of Food Sciences and Food Technology, Institute of Veterinary Medicine \\ and Animal Science, Estonian University of Life Sciences, \\ Kreutzwaldi 62, Tartu, Estonia \\ ${ }^{2}$ Department of Veterinary Science and Public Health, University of Milan, \\ via Celoria 10, 20133 Milan, Italy \\ ${ }^{3}$ Universitat Autonoma de Barcelona, Campus de la UAB, Bellaterra, Spain
}

Received 18 November 2016; Received in revised form 22 December 2016; Accepted 24 December 2016

\begin{abstract}
Most acute intestinal diseases are caused by food-borne pathogens. A fast and simple real-time PCR-based procedure for simultaneous detection of food contamination by any of the five food-borne pathogens: Campylobacter jejuni, Mycobacterium bovis, Enterobacter sakazaki, Shigella boydii, Clostridium perfrigens using multiplex EvaGreen real-time PCR for LightCycler was developed and evaluated. Real-time qPCR showed excellent sensitivity. Tm calling and Melting Curve Genotyping (MCG) were used for analysis of PCR product melting curves. The Melting Curve Genotyping option showed good performance for discrimination of positive samples containing DNA of single pathogen or pathogen mixtures from negative samples.
\end{abstract}

Key words: food-borne pathogens, multiplex real-time PCR, melting curve genotyping

\section{INTRODUCTION}

The frequency of outbreaks of food-borne infection cases worldwide is still extremely high (1) in both the Western world and Third World countries (2). Food pathogens are commonly found in the intestines of healthy food-producing animals, and can be transmitted to humans through contamination in the food chain. Thus, a strict control is required of the whole food chain aimed at enforcing contamination detection measures.

Molecular methods for detection and identification of food pathogens have significant benefits as compared to traditional methods due

Corresponding author: Dr. Avo Karus, $\mathrm{PhD}$

E-mail address: avo.karus@emu.ee

Present address: Department of Food Sciences and Food Technology, Institute of Veterinary Medicine and Animal Science,

Estonian University of Life Sciences, Kreutzwaldi 62, Tartu, Estonia Phone: ++372 7313740; Fax: ++372 7313741

Copyright: (C 2017 Karus A. This is an open-access article published under the terms of the Creative Commons Attribution License which permits unrestricted use, distribution, and reproduction in any medium, provided the original author and source are credited.

Competing Interests: The authors have declared that no competing interests exist.

Available Online First: 3 January 2017

Published on: 15 March 2017

http://dx.doi.org/10.1515/macvetrev-2017-0010 to speed, sensitivity, specificity and accuracy. On the other hand, they often require dedicated instrumentation and higher labour costs. Most molecular methods include an in vitro amplification of nucleic acid via PCR, which is still the most widely applied technique in clinical laboratories. PCR based methods are used to detect, identify and quantify either pathogens or beneficial populations such as fermenting microbes or probiotics $(3,4)$. An advanced real-time PCR based technique has been approved as suitable and convenient diagnostic technique for a wide spectrum of targets in foodborne pathogen detection and can be performed using a variety of instrumentations including capillary equipment (LightCycler 2.0) and platecyclers like LightCycler $480(5,6)$. Multiplex realtime PCR involves simultaneous amplification of more than one locus and thus allows detection of multiple microorganisms in a single reaction. However, the primer sets should be designed with a similar annealing temperature, while providing a method to distinguish between amplicons following thermal cycling (7). It has also been suggested that performing a single, multiplex assay instead of 
several singleplex analyses might reduce the total costs for testing (8).

The objective of the present study was to provide a specific protocol to detect simultaneously food contamination by any of the five foodborne pathogens, namely Campylobacter jejuni, Mycobacterium bovis, Enterobacter sakazaki, Shigella boydii, Clostridium perfrigens. The developed assay can be used to analyse any kind of food, including but not limited to milk, cheese and meat products. The performance of this assay was assessed by using DNA purified by ATCC strains.

\section{MATERIAL AND METHODS}

\section{Samples}

The lyofilized Shigella boydii and Enterobacter sakazaki strains were aerobically grown in a Brain Heart Infusion Broth (Oxoid, Italy) at $37^{\circ} \mathrm{C}$ for 24 hours. Campylobacter jejuni strain was grown in a Brain Heart Infusion Broth (Oxoid, Italy) under a microaerophilic atmosphere ( $\mathrm{CO}_{2} \mathrm{Gen}$, Oxoid, Italy) at $42^{\circ} \mathrm{C}$ for $24-48$ hours. Clostridum perfringens was grown anaerobically, using BBL GasPak ${ }^{\mathrm{TM}}$ Systems (BD, USA), in a Brain Heart Infusion Broth (Oxoid, Italy) at $37{ }^{\circ} \mathrm{C}$ for 48 hours. After overnight incubation from fresh colonies, bacterial cells were collected by centrifugation and subjected to genomic DNA isolation, as previously described (9). The bacterial strains and the isolated genomic DNA are described in Table 1.

For Mycobacterium bovis only genomic DNA was available. The concentration of DNA used for reference target strains varied from 3.9 to $11.2 \mathrm{ng} / \mathrm{ml}$. Pure and mixed samples were prepared using isolated bacterial DNA and NA-free water from Roche Diagnostics (Germany). No real food samples were used.

\section{Primer design}

Primers for real-time PCR amplification were designed using PRIMER EXPRESS (ver. 3.0). Primer pairs were ordered from Tib-MolBiol (Germany) and tested for EvaGreen assays on LightCycler 2.0 ${ }^{\circledR}$ (Roche Diagnostics $\mathrm{GmbH}$ ) using 5x HOTFIREPol ${ }^{\circledR}$ EvaGreen $^{\circledR}$ qPCR Mix Plus (Capillary) with $7.5 \mathrm{mM} \mathrm{MgCl}{ }_{2}$ ready-to use mastermix (Solis BioDyne). Primer sequences and the accession number of target genes are listed in Table 2.

\section{EvaGreen PCR assay}

Quantitative PCR reactions followed by melting curve analysis were performed in a final volume of $20 \mathrm{ml}$ containing $2 \mu \mathrm{l}$ of template genomic DNA, $4 \mu \mathrm{l}$ of $5 \mathrm{x}$ HOT FIREPol ${ }^{\circledR}$ EvaGreen $^{\circledR}$ qPCR Mix Plus (Capillary) with 7,5 $\mathrm{mM} \mathrm{MgCl}_{2}, 5 \mu$ of primer cocktail ( $0.5 \mu \mathrm{l}$ of each forward and reverse primer) and $10 \mathrm{ml}$ of molecular grade water. Tenfold dilutions of the target genomic DNA $(1 \mathrm{ng} / \mathrm{ml}$ and $100 \mathrm{pg} / \mathrm{ml})$ were tested to determine the fair amount of template DNA detected by the assay (PCR sensitivity). The reactions were carried out by using LC Capillaries $20 \mu$ l. Each sample was tested in triplicate with the following thermal profile: $95^{\circ} \mathrm{C}$ for $15 \mathrm{~min}$ for hot-start, followed by 45 cycles at $95^{\circ} \mathrm{C}$ for $15 \mathrm{~s}$, $60^{\circ} \mathrm{C}$ for $20 \mathrm{~s}$ and $72^{\circ} \mathrm{C}$ for $30 \mathrm{~s}$. The melting point analysis was preceded by a denaturation step $95^{\circ} \mathrm{C}$ for $5 \mathrm{~s}$ and an annealing step $65^{\circ} \mathrm{C}$ for $15 \mathrm{~s}$, followed by continuous fluorescence recording from $65^{\circ} \mathrm{C}$ till $90^{\circ} \mathrm{C} 0.05^{\circ} \mathrm{C} / \mathrm{s}$ and a cooling step $40^{\circ} \mathrm{C}$ for $15 \mathrm{~s}$.

Comparison of two different analysis methods: Tm calling versus Melting Curve Genotyping

The melting curve results at $\lambda 530 \mathrm{~nm}$ were analyzed with LightCycler480 SW1.5.0 using two different options: automated Tm Calling

Table 1. Reference target bacterial strains used in this study and primers designed using PRIMER EXPRESS (ver. 3.0)

\begin{tabular}{ccccccc}
\hline Species & Strain & $\begin{array}{c}\text { Gene } \\
\text { target }\end{array}$ & Primer forward & Tm & Primer reverse & Tm \\
\hline Shigella boydii & $\begin{array}{c}\text { DSM } \\
7532 \mathrm{~T}\end{array}$ & ipaH2 & GATACCGTCTCTGCACGCAAT & $59^{\circ} \mathrm{C}$ & GCCATGCAGCGACCTGTT & $59^{\circ} \mathrm{C}$ \\
$\begin{array}{c}\text { Campylobacter } \\
\text { jejuni }\end{array}$ & $\begin{array}{c}\text { DSM } \\
4688 \mathrm{~T}\end{array}$ & $\mathrm{CadF}$ & GTGGCAAAAAGGAAAAAGCTGTA & $59^{\circ} \mathrm{C}$ & $\mathrm{CATTTTGCTTGTGGAGTTGCA}$ & $58^{\circ} \mathrm{C}$ \\
$\begin{array}{c}\text { Mycobacterium } \\
\text { bovis }\end{array}$ & $\begin{array}{c}\mathrm{DSM} \\
43990\end{array}$ & Hsp & GGGTCAAGCTCGACGTTGA & $58^{\circ} \mathrm{C}$ & CGGTGGTCCGTTTGGAACT & $58^{\circ} \mathrm{C}$ \\
$\begin{array}{c}\text { Enterobacter } \\
\text { sakazakii }\end{array}$ & $\begin{array}{c}\text { DSM } \\
18702 \mathrm{~T}\end{array}$ & AY748357 & GCGCGGTGTGTCAGAGTCT & $59^{\circ} \mathrm{C}$ & AACCTCACAACCCGAAGAAGTC & $58^{\circ} \mathrm{C}$ \\
$\begin{array}{c}\text { Clostridium } \\
\text { perfringens }\end{array}$ & DSM & a toxin & GCATGAGTCATAGTTGGGATGATT & $58^{\circ} \mathrm{C}$ & TGCTGTTCCTTTTTGAGAGTTAGCT & $59^{\circ} \mathrm{C}$ \\
\hline
\end{tabular}

DSM - Strains obtained from the German Collection of Microorganisms and Cell Cultures, Braunschweig (Germany) 
and Melting Curve Genotyping to investigate the potential to identify the pathogens via qPCR product melting peak and melting profile. Both analyses were used only for samples with Ct less than 37 in quantitative analysis.

\section{RESULTS}

Analytical sensitivity and specificity

In multiplex testing, sensitivity was detected by analysis of tenfold dilution series of bacterial DNA. The detection of $100 \mathrm{pg}$ of pathogen DNA was confirmed (Table 2).
Shigella boydii, Clostridium perfrigens. In samples containing artificial mixtures of pathogens DNA, usually no more than two major pathogens were identified by melting curve analysis. However, in all capillaries no false-positive or false-negative results were generated, confirming the excellence of the developed assay (Fig. 1).

\section{Intra- and inter-assay reproducibility}

To obtain values for the intra- and inter-assay variation of the assay, $1 \mathrm{ng}$ and $100 \mathrm{pg}$ of purified genomic DNA was analyzed in triplicate. The coefficients of variation $(\mathrm{CV})$ of the $\mathrm{Ct}$ values ranged from 0.5 to $2.1 \%$ for intra-assay experiments

Table 2. Threshold cycle $\left(\mathrm{C}_{\mathrm{T}}\right)$ of quantification analysis obtained in 10-fold dilution of the pure culture genomic DNA (1 ng and $100 \mathrm{pg}$ ) and major melting peaks of amplicons

\begin{tabular}{lcccccccc}
\hline & $\mathbf{1 ~ n g} / \boldsymbol{\mu l}$ & \multicolumn{3}{c}{$\mathbf{1 0 0} \mathbf{~ p g} / \boldsymbol{\mu l}$} & \multicolumn{5}{c}{ Melting peaks (Tm)* } \\
\hline EvaGreen assay & Avg CT & sd & Avg CT & sd & Tm1 & sd & Tm2 & sd \\
Shigella boydii & 31.72 & 0.82 & 35.12 & 0.83 & 81.85 & 0.19 & \\
Campylobacter jejuni & 33.65 & 1.18 & 37.01 & 1.24 & 80.99 & 0.03 & \\
Mycobacterium bovis & 31.54 & 0.84 & 34.92 & 0.81 & 81.16 & 0.15 & 84.32 & 0.05 \\
Enterobacter sakazaki & 22.14 & 0.88 & 25.49 & 0.96 & 80.71 & 0.16 & & \\
Clostridium perfrigens & 22.10 & 1.00 & 25.43 & 1.03 & 77.38 & 0.19 & \\
\hline
\end{tabular}

* Variability of Tm was calculated in DNA cocktail analyses and standard deviations (sd) are shown; Mycobacterium bovis showed two melting peaks

The melting curves for PCR products were analyzed by two methods, while specificity of the multiplex assay was confirmed by testing against all five targets: Campylobacter jejuni, Mycobacterium bovis, Enterobacter sakazaki, and from 2.3 to $4.5 \%$ for inter-assay experiments.

The coefficients of variation of the Tm values ranged from 0.05 to $0.21 \%$ for intra-assay experiments and from 0.06 to $0.25 \%$ for inter-assay experiments.

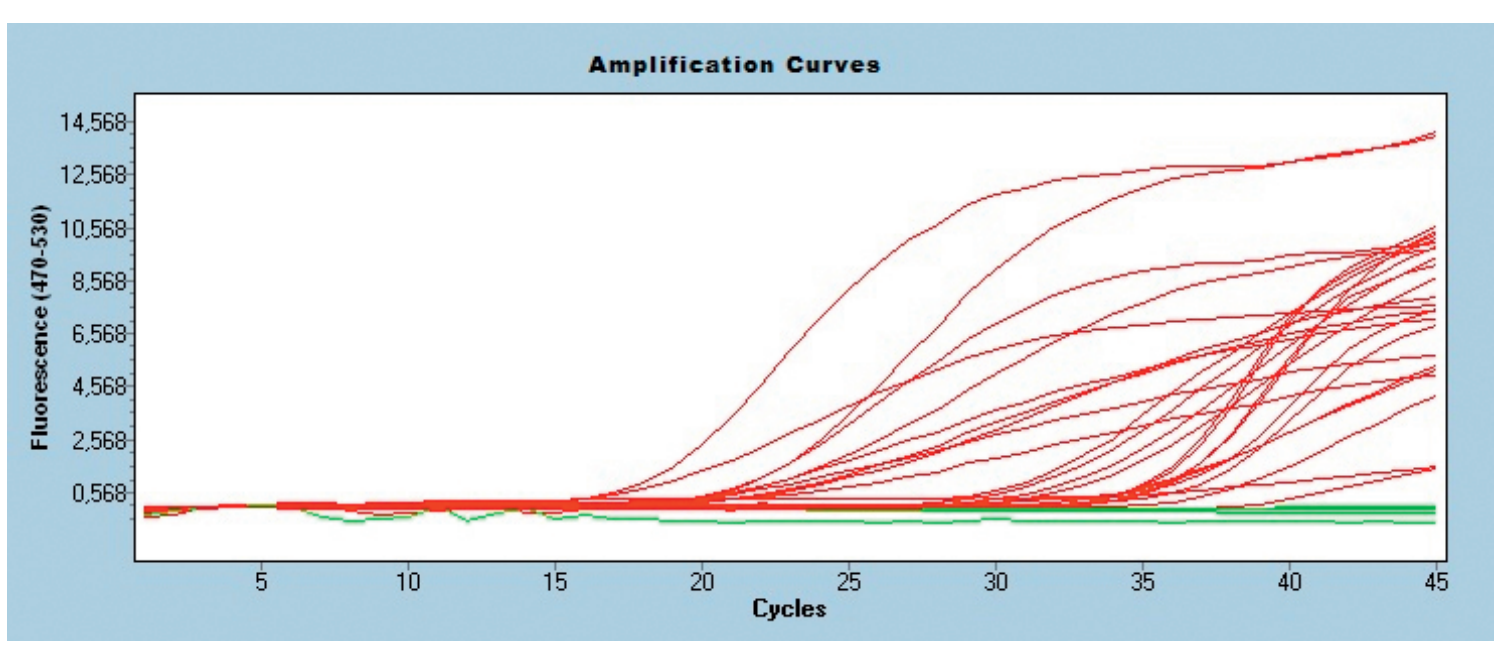

Figure 1. Amplification curves of EvaGreen assays in multiplex test with DNA cocktails

Positive and/or spiked samples

Negative samples 


\section{Tm calling versus Melting Curve Genotyping}

The robustness of the assay was evaluated by comparative analysis of PCR product melting curves using different software features - Tm calling and Melting Curve Genotyping (MCG). did not allow identifying the minor components, especially if three pathogens were mixed for analysis.

Melting Curve Genotyping showed similar performances, but because the basis for identification is the melting curve pattern,

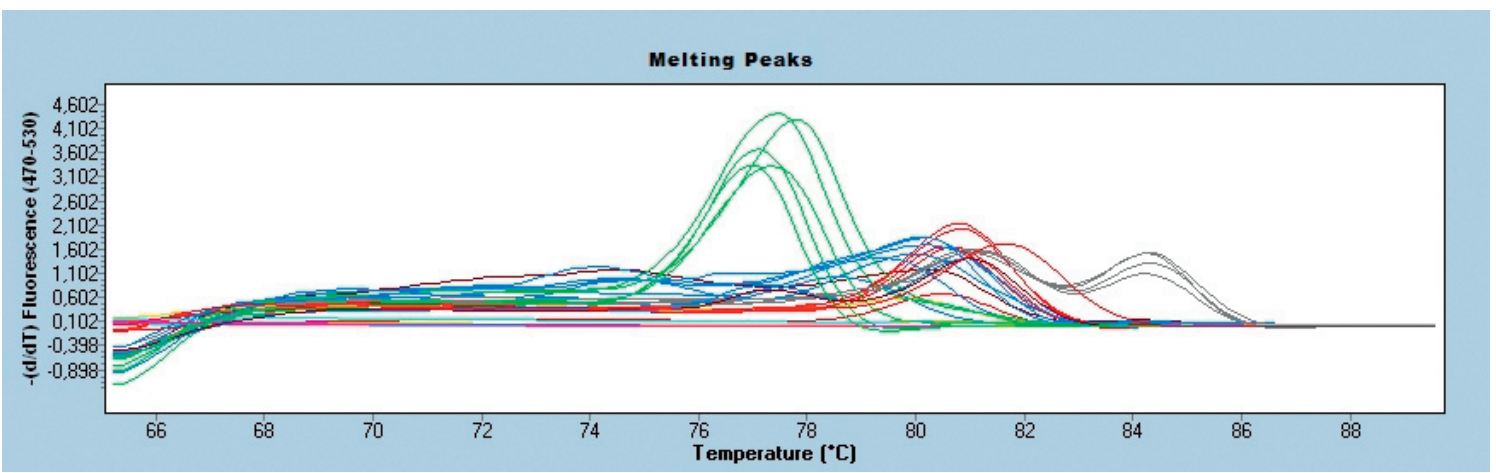

Figure 2. Species identification in melting curves using melting point genotyping feature of LightCycler 480 software for DNA cocktails

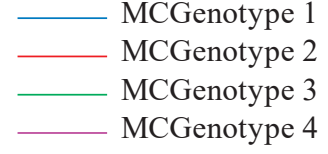

Tm calling allowed the identification of PCR products by major product(s) melting temperature, however in MCG the pattern of the melting curve was identified. Tm calling showed clear differentiation of samples with single pathogen genomic DNA as shown in Table 2. In mixed samples (containing DNA from two or more pathogen) the major component was always identified, thus the food would be rejected in any pathogen contamination included in the assay. However, the procedure
MCGenotype 5

MCGenotype 6

Negative

Other genotypes

Table 3. Melting Curve Genotyping results for different pathogen DNA cocktails

\begin{tabular}{|c|c|c|c|c|}
\hline MC Genotype & & DNA cocktails incl & y MCG SW & \\
\hline 1 & $\mathrm{ES}+\mathrm{MB}+\mathrm{CJ}+\mathrm{CP}+\mathrm{SB}$ & & & \\
\hline 2 & ES & $\mathrm{ES}+\mathrm{MB}+\mathrm{CJ}$ & $\mathrm{ES}+\mathrm{CJ}$ & $\mathrm{ES}+\mathrm{MB}(1 / 10)$ \\
\hline 3 & $\mathrm{CP}$ & $\mathrm{CP}+\mathrm{SB}$ & $\mathrm{CP}+\mathrm{MB}(1 / 10)$ & \\
\hline 4 & $\mathrm{CJ}+\mathrm{ES}+\mathrm{MB}$ & $\mathrm{CJ}+\mathrm{SB}$ & $\mathrm{CJ}+\mathrm{CP}+\mathrm{SB}+\mathrm{MB}$ & \\
\hline 5 & MB & $\mathrm{MB}(1-1 / 3)+\mathrm{ES}$ & $\mathrm{MB}(1-1 / 3)+\mathrm{CJ}$ & \\
\hline 6 & CJ & $\mathrm{CJ}+\mathrm{ES}(1 / 3)$ & & \\
\hline Negative & Negative control & & & \\
\hline Other genotypes & All other variants & & & \\
\hline
\end{tabular}




\section{DISCUSSION}

It is generally accepted (10), that prevention of food-borne disease basically depends on surveillance and prompt identification of pathogens in food products. The major advantage of the current molecular method is the lower price and the short time necessary to obtain the results.

A crucial step for molecular assessment of microbial communities is the selection of a gene or a genetic marker that can be used to differentiate a wide variety of organisms (11). Usually, the specificity of assays is ensured by using hydrolysis or hybridization probes (3). Indeed, any of all additional chemistries, even the most widely used TaqMan ${ }^{\circledR}$ chemistry, will significantly increase the costs of assay.

Several real-time PCR assays for single reaction have been developed for the detection of the pathogens subjects of our interest and the trend has been moving towards strategies for rapid identification of more than one pathogen through the development of multiple analysis platforms $(12$, $13,14,15)$.

The real-time PCR assay described in this study has the potential to be a fast screening assay for several pathogens, enabling simultaneous processing of many food samples. Because the assay development does not include the sample preparation steps, the only prerequisite is to obtain good quality (good purity and sufficient concentration) purified DNA from various samples and is not limited to food, but can also be used for HACCP (analysing surfaces, etc.) risk analysis or other goals.

\section{CONCLUSION}

In conclusion this assay may be used for accurate and rapid diagnosis of food-borne outbreaks, it has the potential to be used in routine diagnostic laboratories providing a simple, fast, cheap and sensitive alternative method to culture-based or TaqMan qPCR methods.

\section{CONFLICT OF INTEREST STATEMENT}

The authors declared that they have no potential conflict of interest with respect to the authorship and/or publication of this article.

\section{ACKNOWLEDGEMENT}

This work was supported by a Grant from INTERREG IVC, financed by the European Regional Development Fund within the project "Innovation 4 Welfare" - subproject "FOBOS -Sharing molecular techniques for food-borne pathogen detection"

\section{REFERENCES}

1. Fleckenstein, JM., Bartels, SR., Drevets, PD., Bronze, MS., Drevets, DA. (2010). Infectious agents of food- and water-borne illnesses. Am J Med Sci, 340(3): 238-246.

https://doi.org/10.1097/MAJ.0b013e3181e99893

2. Postollec, F., Falentin, H., Pavan, S., Combrisson, J., Sohier, D. (2011). Recent advances in quantitative PCR (qPCR) applications in food microbiology. Food Microbiol, 28(5): 848-861.

https://doi.org/10.1016/j.fm.2011.02.008

PMid:21569926

3. Severgnini, M., Cremonesi, P., Consolandi, C., De Bellis, G., Castiglioni, B. (2011). Advances in DNA Microarray technology for the detection of foodborne pathogens. Food Bioproc Tech, 4, 936953.

https://doi.org/10.1007/s11947-010-0430-5

4. Jošić D., Petković J., Bunčić O., Lepšanović Z., Pivić R., Rašić Z., Katić V. (2016). Typing of indigenous Campylobacter spp. from Serbia by M-PCR and RAPD. Acta Veterinaria-Beograd, 66 (2): 203-213.

https://doi.org/10.1515/acve-2016-0017

5. Fukushima, H., Katsube, K., Hata, Y., Kishi, R., Fujiwara, S. (2007). Rapid separation and concentration of food-borne pathogens in food samples prior to quantification by viable-cell counting and real-time PCR. Appl Environ Microbiol, 73(1): 92-100.

https://doi.org/10.1128/AEM.01772-06

PMid:17056684 PMCid:PMC1797114

6. Fukushima, H., Kawase, J., Etoh, Y., Sugama, K., Yashiro, S., Iida, N., Yamaguchi, K. (2010). Simultaneous screening of 24 target genes of foodborne pathogens in 35 foodborne outbreaks using multiplex real-time SYBR green PCR analysis. International Journal of Microbiology 12010, Article ID 864817, 18 pages. https://doi.org/10.1155/2010/864817

7. Zhao, X., Lin, C-W., Wang J., Oh, D.H. (2014). Advances in rapid detection methods for foodborne 
pathogens. J.Microbiol.Biotechnol 24(3): 297-312.

https://doi.org/10.4014/jmb.1310.10013

PMid:24375418

8. Binnicker, MJ. (2015). Multiplex molecular panels for diagnosis of gastrointestinal infection: performance, result interpretation, and costeffectiveness. J.Clin.Microbiol. 53,3723-3728. https://doi.org/10.1128/JCM.02103-15

9. Cremonesi, P., Pisani, L. F., Lecchi, C., Ceciliani, F., Martino, P., Bonastre, A. S., Karus, A., Balzaretti, C., Castiglioni, B. (2014). Development of 23 individual TaqMan ${ }^{\circledR}$ real-time PCR assays for identifying common foodborne pathogens using a single set of amplification conditions. Food Microbiol, 43, 35 - 40. https://doi.org/10.1016/j.fm.2014.04.007

PMid:24929880

10. Amagliani, G., Omiccioli, E., Campo, A., Bruce, IJ., Brandi, G., Magnani, M. (2006). Development of a magnetic capture hybridization-PCR assay for Listeria monocytogenes direct detection in milk samples. J Appl Microbiol. 100(2): 375-383. https://doi.org/10.1111/j.1365-2672.2005.02761.x PMid:16430514

11. Justé, A., Thomma, BP., Lievens, B. (2008). Recent advances in molecular techniques to study microbial communities in food-associated matrices and processes. Food Microbiol. 25(6): 745-761. https://doi.org/10.1016/j.fm.2008.04.009 PMid:18620966
12. Elizaquível, P., Aznar, R. (2008). A multiplex RTi-PCR reaction for simultaneous detection of Escherichia coli O157:H7, Salmonella spp. and Staphylococcus aureus on fresh, minimally processed vegetables. Food Microbiol. 25(5): 705-713.

https://doi.org/10.1016/j.fm.2008.03.002

PMid:18541170

13. Kawasaki, S., Fratamico, PM., Horikoshi, N., Okada,Y., Takeshita,K., Sameshima, T., Kawamoto,S. (2010). Multiplex real-time polymerase chain reaction assay for simultaneous detection and quantification of Salmonella species, Listeria monocytogenes, and Escherichia coli O157:H7 in ground pork samples. Foodborne Pathog Dis. 7(5): 549-554.

https://doi.org/10.1089/fpd.2009.0465

PMid:20132032

14. Omiccioli, E., Amagliani, G., Brandi, G., Magnani, M. (2009). A new platform for RealTime PCR detection of Salmonella spp., Listeria monocytogenes and Escherichia coli O157 in milk. Food Microbiol. 26(6): 615-622.

https://doi.org/10.1016/j.fm.2009.04.008 PMid:19527837

15. Suo, B., He, Y., Tu, SI., Shi, X. (2010). A multiplex real-time polymerase chain reaction for simultaneous detection of Salmonella spp., Escherichia coli O157, and Listeria monocytogenes in meat products. Foodborne Pathog Dis. 7(6): 619-628. https://doi.org/10.1089/fpd.2009.0430 PMid:20113204

Please cite this article as: Karus A., Ceciliani F., Bonastre SA., Karus V. Development of simple multiplex real-time PCR assays for foodborne pathogens detection and identification on LightCycler. Mac Vet Rev 2017; 40 (1): 53-58. http://dx.doi.org/10.1515/macvetrev-2017-0010 